\title{
Implementation of Intellectual Property Management Centre in Order to Legal Protection of Creative Industrial Products in Yogyakarta
}

\author{
Dyah Permata Budi Asri ${ }^{1}$ \\ $\{$ dyah@janabadra.ac.id\} \\ ${ }^{1}$ Faculty of Law Janabadra University, Jalan Tentara Rakyat Mataram 55-57 Yogyakarta, Indonesia
}

\begin{abstract}
The aim of this research is to find out the importance of IPR for MSMEs and to analyze the institutional implementation of the Intellectual Property Management Center in order to provide protection for MSME creative products in Yogyakarta. This research method uses qualitative research methods using primary data from the field and secondary data from references and documents. The results of this study obtained an analysis that the importance of IPR protection on MSME creative products especially to provide legal protection if there is a violation of the MSME intellectual work. In addition, the role of BPKI is felt to be very helpful, especially in increasing MSME awareness of IPR registration due to the various work programs of Intellectual Property Management Centre namely advocacy, assistance and facilitation of IPR
\end{abstract}

Keywords: Intellectual Property Right's , Micro Small Medium Enterprises, Intellectual Property Management Center

\section{Introduction}

Nowadays community innovation is developing so rapidly. Many innovative products are produced by creative industry groups in Indonesia, where the creative industries in Indonesia have a major role in the country's economy and are one of the contributors to the country's foreign exchange. In Indonesia, the creative industry is often referred to as Micro Small Medium Enterprises (MSME's), which from year to year its existence has increased in number. This is because businesses in the MSME's sector are very promising even though the country is in the midst of a hurricane / economic crisis that has a gap, but it is believed that the creative industries (MSME's) are able to withstand such conditions.

MSME's can also be a buffer, especially for employment and socio-economic communities, so far the number of MSMEs in Yogyakarta up to the end of 2015 is 137,267, which continues to experience economic growth of $10 \%$ annually.[1] According to the explanation in Act Number 20 Year 2008 concerning Micro, Small and Medium Enterprises, MSME's is a business activity that is able to expand employment and provide broad economic services to the community, and can play a role in the process of equity and increase in community income, encourage economic growth and play a role realizing national stability. 
Creative industries have considerable potential to be developed and can become a mainstay of the national economy. Creative industry is an industry that produces a variety of products that are related to the process of manifesting an idea or ideas into intellectual property that has high economic value for the welfare and employment of the people and can increase the economic growth of a country. Creative industries are formulated as economic activities that include industries with creative human resources (HR) as the main assets to create economic added value. [2].

The rapid growth of MSME's in Yogyakarta must be balanced with the support of government agencies. The number of MSME's in Yogyakarta is unaware of the importance of protecting Intellectual Property Rights for their creative products. Protection of Intellectual Property Rights is the spearhead of the protection of MSME creative products where the main objective is to provide legal protection and guarantee the welfare of its people. Legal protection of MSME's creative products through a first to file system that is legal protection of creative products will be protected by the state for the party who is first applied for registration. The Intellectual Property Rights System is an individual right. Because of its nature which is the individual's rights, a person is free to submit an application or register his intellectual work or not register. [3] With legal protection efforts for MSME's creative products, in reality the community is still faced with bureaucratic challenges that are too complicated and also take a lot of time starting from licensing and fulfillment of registration requirements, lack of public education about IPR registration so that IPR protection is not considered important by the community, also the role of government does not accommodate the legal protection of the ability of MSME's practitioners in the Yogyakarta community, which can be later almost the target for IPR protection. The fact that the market potential of creative works at home and abroad is very large and has a tendency to continue to grow, further reinforcing the reason for the importance of protecting intellectual property rights (IPR) on creative economic products with the aim that the originator of creative ideas and innovations get economic benefits for his intellectual work.

In Indonesia, the institution tasked with providing services for filing applications for IPR registration is the Directorate General of Intellectual Property (DJKI) under the Ministry of Law and Human Rights of the Republic of Indonesia. So, it can be ascertained that the submission of IPR applications requires a relatively long time. In Yogyakarta, there is an institution that deals with IPR registration for MSME`s, the Intellectual Property Service Center (BPKI), which is an institution under the Yogyakarta Provincial Industry and Trade Office. BPKI was formed with the Governor Regulation DIY Number 98 of 2018 concerning the Establishment, Organizational Structure, Duties, Functions and Work Procedures of the Technical Implementing Units at the Yogyakarta Special Industry and Trade Office.

In an effort to achieve the goal of IPR registration for MSME's it is needed cooperation of all parties both the business world, government and society. For this reason, government intervention is needed in encouraging the advancement of the creative industry through coaching related to IPR protection for MSME's creative products. In this context the problem examined in this paper is how the role of institutions in the framework of IPR registration for MSMEs in synergy to support innovative products in order to provide legal protection in Indonesia. Therefore this paper aims to review and explain the role of government institutions and their efforts to increase the number of IPR registrations for MSME's. This paper is the result of Applied Grant Research funded by the Ministry of Research, Technology and Higher Education Budget for 2019-2020. 


\section{Method}

This research is a qualitative research using Empirical Juridical approach. Yogyakarta City is the location of this research. The method of data collection is through library research studies, documents, and field studies with resource persons at the Intellectual Property Management Center. The analytical method starts from data collection, data reduction, data presentation and drawing conclusions.

\section{Results and Discussion}

\subsection{The Importance of Legal Protection for Intellectual Property Rights for MSME Creative Products}

Intellectual Property Rights (IPR) registration is important because it does not rule out the possibility that this IPR can be a trigger to bring up new innovations for companies that can ultimately benefit the public as well as the company itself. IPR is also a source of material wealth for its owner because it has economic value. In industrial and trade activities, economic benefits can not only be enjoyed by the owner, but also by other parties.

Property Rights attached to the term IPR cannot be separated from the economic value of a property as part of material rights. The economic right is in the form of profits from the amount of money obtained due to the use of IPR itself, or because the use of IPR by other parties based on a license. The fact that there is economic value shows that IPR is one of the objects of trade [4]. In accordance with the times, the protection of the rights possessed by every human being requires an arrangement, including the case with IPR. [5]. In general, IPR is divided into two categories, namely Copyright and Industrial Property Rights. Industrial Property Rights are divided into 6 (six) types of IPR, namely: Patents, Trademarks and Geographical Indications, Industrial Designs, Layout Designs of Integrated Circuits, Trade Secrets, and Plant Variety Breeding.

IPR registration provides legal protection consequences. Intellectual works are born with sacrifices that make works that are economically valuable, especially with economic benefits that can be enjoyed, the inherent economic value grows the concept of wealth (intellectual property) of intellectual works for the business world, or those works can be said as an asset. Exclusive rights granted by law are an appropriate reward for investors and creators of IPR [6]. These lawful rights give an elite right to the designer or maker or their appointment to completely use their development / creation for a given time frame. It is very much settled that IP is assumed to be an essential job in the advanced economy [7]. Through these rewards, creative people are encouraged to continue to hone their intellectual abilities so they can be used to help improve human life. The main purpose of the IPR legal system is to ensure that the creative process continues by providing adequate legal protection and providing sanctions against those who use the creative process without permission.

The main objective of legal protection is the legal certainty of the people of Indonesia in order to guarantee the rights obtained as citizens and secure protection and welfare in accordance with the provisions in the legal regulations. According to Setiono, legal protection is an act or an effort to protect the community from arbitrary acts by the authorities that are not in accordance with the rule of law, to realize order and peace so as to enable humans to enjoy their dignity as human beings. [8]. Legal protection is an illustration of the operation of the legal function to realize legal objectives, namely justice, usefulness and legal certainty. Legal 
protection is a protection given to legal subjects in accordance with the rule of law, both those that are preventive (preventive) and in the form of repressive (coercive), both written and unwritten in the context of enforcing the rule of law. The law itself in its form as a rule clearly can not do all that. Thus it becomes relevant to discuss the factors that influence law enforcement.

These factors according to Soerjono Soekanto are as follows: factors of the rule of law/ regulation itself, factors of law enforcement officers / facilities, factors of facilities or facilities, factors of society and cultural factors. [9]. This opinion is in line with that expressed by Lawrent Friedman who states that law enforcement is influenced by three things, namely legal subtance, legal structure, legal culture. The factors mentioned above are interrelated, because it is the essence of law enforcement and is a benchmark of the effectiveness of law enforcement. Likewise, the protection of IPR can be qualified as a repressive and preventive legal effort. Preventive legal measures are seen in the regulation of IPR in a number of laws and regulations, while repressive legal measures are seen in the regulation of criminal acts in the provisions mentioned above.

In the Indonesian economy, Micro, Small and Medium Enterprises (MSME's) are the business groups that have the largest number and are proven to be resistant to various kinds of economic crisis shocks. The important role for MSME“s in economic development in Indonesia needs to be taken into account, especially related to the creative and innovative products produced, besides that MSME's are able to create a wide range of employment opportunities and provide economic services to the wider community. Currently there is a shift in the world economic order that leads to free economic competition so that with this condition it needs special attention from the government related to the threat of counterfeiting products produced by MSME's as well as a decrease in creativity and innovation due to the imitation threat and counterfeiting of creative industry products . In addition, threats also come from the external side, namely in the face of intense competition with similar businesses. Products produced by MSME's are products that are born from intellectual abilities so they are products related to IPR. This is the reason why MSME's are very closely related to IPR, and in terms of legal protection is important in order to protect the products of creative industries.

Awareness of IPR by MSME's is still very low, which causes the potential for violations of IPR from products produced by MSME's so that the economic rights that MSME's should have over intellectual work are lost. So that it will undoubtedly cause a loss of the economic value of an SME product. [10]

\subsection{The Role of the Intellectual Property Management Center in the Intellectual Property Rights Registration Service for Micro, Small and Medium Enterprises}

The Intellectual Property Service Center is an institution that provides IPR services for SME's, where the Intellectual Property Service Center is an institution under the Yogyakarta Special Industry and Trade Office. The Intellectual Property Service Center was formed with the regulation of the Governor of DIY Number 98 of 2018 concerning the formation, organizational structure, tasks, functions and work procedures of the technical implementing units in the Department of Industry and Trade of the Special Region of Yogyakarta [11]. Intellectual Property Service Center has a vision "As a competent and professional public service unit in improving the competitiveness of MSME' $s$ " and Mission "The realization of an integrated service that is able to lift the image of business people with coaching, training, consultation, advocacy, facilitation of IPR" 
The Intellectual Property Service Centre has a role in providing services to MSME`s such as: Consultation on intellectual property rights; Facilitation of registration of intellectual property rights; Issuance of MSME's recommendations; Issuance of co-branding licenses; and advocacy and education. For now consultation by the Intellectual Property Service Center can be done directly by visiting the Intellectual Property Service Center office or through https://disperindag.jogjaprov.go.id/haki/ Online connected to whatsapp application, this is done to facilitate the community for the information needs of IPR registration.

Data on the number of IPR registrants in the Special Region of Yogyakarta are as follows:

Table 1. Submission of UKM IPR in DIY

\begin{tabular}{|r|l|l|}
\hline No. & \multicolumn{1}{|c|}{ Regency/City } & \multicolumn{1}{|c|}{ Amount } \\
\hline 1. & Yogyakarta City & 354 \\
\hline 2. & Bantul Regency & 205 \\
\hline 3. & Sleman Regency & 260 \\
\hline 4. & Kulonprogo Regency & 67 \\
\hline 5. & Gunung Kidul Regency & 44 \\
\hline
\end{tabular}

In addition to general IPR registration services for MSMEs, the BPKI also facilitates registration of intellectual property which is one of the programs aimed at helping the public from IPR registration fees with a financing burden of Rp. 0 (free). All costs of facilitating intellectual property are charged to the Regional Expenditure Planning Budget and the Privileged Budget. The intellectual property that can be registered are trademarks, collective marks, geographical indications, patents, copyrights, industrial designs. In accordance with the mandate of Yogyakarta Special Region Regulation Number 9 Year 2017 Concerning Empowerment and Protection of Creative Industries, Cooperatives and Small Businesses the fifth part of article 28 which states "Local Government provides facilitation of intellectual property rights, halal certification, home industry food permits as referred to in Article 19 paragraph (2) letter d to individuals or the community in accordance with the provisions of the legislation."

The following is the facilitation recap data carried out by the 2019 Intellectual Property Service Center:

Table 2. Facilitation Recap of 2019

\begin{tabular}{|l|l|l|}
\hline No. & \multicolumn{1}{|c|}{ Types of Goods Facilitation Types } & \multicolumn{1}{|c|}{$\begin{array}{c}\text { Types of Goods } \\
\text { Facilitation Types }\end{array}$} \\
\hline 1. & Handycraft Clay Pottery Statue & Brand \\
\hline 2. & Juice drinks & Brand \\
\hline 3. & Processed rendang packaging & Brand \\
\hline 4. & Restaurant & Brand \\
\hline 5. & Processed chicken meat packaging & Brand \\
\hline 6. & Wet cakes and pastries & Brand \\
\hline 7. & puzzle & Brand \\
\hline 8. & Processed fish & Brand \\
\hline
\end{tabular}




\begin{tabular}{|l|l|l|}
\hline 9. & $\begin{array}{l}\text { Pickled fruits and vegetables, meatball } \\
\text { tofu }\end{array}$ & Brand \\
\hline 10. & Chocolate drink & Brand \\
\hline
\end{tabular}

In addition to general IPR registration services for MSME', the BPKI also facilitates registration of intellectual property which is one of the programs aimed at helping the public from IPR registration fees with a financing burden of Rp. 0 (free). All costs of facilitating intellectual property are charged to the Regional Expenditure Planning Budget and the Privileged Budget. The intellectual property that can be registered are trademarks, collective marks, geographical indications, patents, copyrights, industrial designs. In accordance with the mandate of Yogyakarta Special Region Regulation Number 9 Year 2017 Concerning Empowerment and Protection of Creative Industries, Cooperatives and Small Businesses the fifth part of article 28 which states "Local Government provides facilitation of intellectual property rights, halal certification, home industry food permits as referred to in Article 19 paragraph (2) letter $\mathrm{d}$ to individuals or the community in accordance with the provisions of the legislation. "

The following is the facilitation recap data carried out by the 2019 Intellectual Property Service Center:

Table 3. Facilitation Recap of 2019

\begin{tabular}{|c|c|c|}
\hline No. & Type of co branding & Amount \\
\hline 1. & Jogjamark & 171 \\
\hline 2. & $100 \%$ Jogja & 8 \\
\hline 3. & Jogjatradition & 1 \\
\hline
\end{tabular}

Advocacy and education on Intellectual Property Rights is carried out to provide an understanding of the protection of Intellectual Property to the people of the Special Region of Yogyakarta, advocacy and education is carried out by the Intellectual Property Service Center on a regular basis to MSME actors. In addition to the programs implemented above, the Intellectual Property Service Center also carries out public service publications, advertisements on radio, talk shows, and organizes IPR communication forums as an effort to inform the public of the importance of intellectual property protection.

To carry out its role and function, the Intellectual Property Service Center also conducts and fosters relations with various agencies and working partners, namely: Directorate General of Intellectual Property, Ministry of Law and Human Rights; Ministry of Industry; Ministry of Trade; DIY Regional Office of the Ministry of Law and Human Rights; Ministry of Research Technology and Higher Education; Creative Economy Agency; KPD Related (DIY \& Regency / City); Indonesian Intellectual Property Center Association (SKII); and various Higher Education IPR Centers such as Gajahmada University, Indonesian Islamic University, Yogyakarta Veterans University, Sunan Kalijaga State Islamic University, Yogyakarta Muhamadiyah University, Yogyakarta Janabadra University, Yogyakarta "Amikom" STMIK, Yogyakarta Academy of Industry, Yogyakarta State University, and Ahmad Dahlan University.

\section{Conclusion}

MSME's is a promising creative industry in Indonesia. Many creative industries produce creative products that come from intellectual property that has a high economic value. Therefore 
we need the protection of these creative products to prevent violations of ownership or utilization of the creative products.

BPKI is an institution that deals with intellectual property services for MSME's. The services are in the form of socialization, advocacy, and IPR education, IPR management assistance, facilitation of filing IPR applications and Jogja Co Barnding facilitation for MSMEs. In addition to carrying out its functions and duties, BPKI also collaborates with various Ministries and Intellectual Property Centers in various universities. With the role of BPKI in the management and service of IPR at MSME's, it is expected that an increase in the number of IPR registrations for MSME's, due to increased awareness of IPR for MSME's.

\section{Acknowledgments}

This research was supported by the Directorate of Research and Community Service, Ministry of Technology Research and Higher Education, the Republic of Indonesia. We thank our colleagues from the Department of Industry and Trade Province of Special Region of Yogyakarta through the Intellectual Property Management Center who provided insight and expertise that greatly assisted the research.

\section{References}

[1] Asri, D. P. B., Pengembangan Industri Kreatif UMKM Asal Yogyakarta Melalui Pendaftaran" Jogja Co Branding". Kosmik Hukum, 18(2), (2018).

[2] Departemen Perdagangan Republik Indonesia, Pengembangan Ekonomi Kreatif Indonesia 2025, Jakarta, Depdag RI, 2008, hlm. 2

[3] Asri, Dyah Permata Budi. "Legal protection of culture in Indonesia through the World Heritage Center UNESCO." Culture and International Law: Proceedings of the International Conference of the Centre for International Law Studies (CILS 2018), October 2-3, 2018, Malang, Indonesia. CRC Press, p.87, (2019).

[4] Tatty Aryani Ramli, dkk., "Urgensi Pendaftaran Indikasi Geografis Ubi Cilembu Untuk Meningkatkan IPM", Jurnal Sosial dan Pembangunan Mimbar, Vol. 26, No. 1 Tahun 2010, hal. 80-81

[5] Djulaeka, Konsep Perlindungan Hak Kekayaan Intelektual: Prespektif Kajian Filosofis HAKI Kolektif-Komunal, Malang: Setara Press, 2014, hlm.. 1.

[6] Sufiarina, Hak Prioritas Dan Hak Eksklusif Dalam Perlindungan HKI, Adil, Journal of Law, Universitas Yarsi, Vol.3 Nomor 2, Tahun 2015, hlm 269

[7] Saha Chandra Nath, Sanjib Bhattacharya, Intellectual property rights: An overview and implications in pharmaceutical industry, Journal of Advanced Pharmaceutical Technology \& Research, Apr-Jun 2011, Vol 2, Issue 2, 88-93, (2011)

[8]. Setiono, Rule of Law(Supremasi Hukum), (Surakarta; Magister Ilmu Hukum Program Pascasarjana Universitas Sebelas Maret, 2004) hal. 3.

[9] Soerjono Soekanto, Faktor-Faktor Yang Mempengaruhi Penegakan Hukum, Jakarta: Rajawali Pers, 2008, hlm. 9.

[10] Asria, Dyah Permata Budi, and Edy Sriyonoc Sudiyanab. "Demystifying Intellectual Property Rights in the Creative Industry SMES." Vol. 12 Issue 12, 2020, International Journal of Innovation, Creativity and Change (2020)

[11]. Asri, D. P. B, dkk., Hasil Pelaksanaan Penelitian, "Model Pengembangan Pelayanan Kekayaan Intelektual Berbasis Website Pada Balai bisnis dinas perindustriana dan perdagangan daerah istimewa yogyakarta", (2019). 